\title{
Some key policy issues related to technology change, knowledge and absorption capacities in a country comparison perspective
}

\author{
Roberta Benini ${ }^{1}$
}

Published online: 23 July 2016

(C) Springer Science+Business Media New York 2016

\section{Introduction}

This double Special Issue is focused on innovation, knowledge transfer and technological change in emerging, transition and advanced economies, in order to highlight specificities or similarities from the policy perspective. The heterogeneity of the different countries, in term of economic development' level, market institutions' maturity, technology and innovation capacity, make particularly difficult to suggest some conclusions. Therefore, the scope of this Special issue is mainly to underline some crucial questions related to policies and strategies, referring to the different economic and institutional contexts.

Michael Porter' "Diamond of National Advantage" (Porter 1990) for improving national competitiveness, at the core of which there are innovation and productivity growth, refers to mature economies where "factor conditions"-including the quality of labour and other inputs, "the demand conditions" for specific products, "the related supporting industries" and the "firm' strategy and environment, including rivalry" - necessary element to stimulate innovation-are dynamically interrelated. The balance among these fundamental components for an ideal wellfunctioning market, has become also part of long-term strategy for catching up of emerging economies (Kim 1997) adapting them to the respective socio-economic development conditions. Few emerging countries have achieved good resultslooking for improving their capacity to adapt and absorb technology, upgrading their domestic resources, and apply innovation coming from abroad, as long as institutions have been able to become facilitator and propellant of such structural changes.

Roberta Benini

rbenini2@gmail.com

1 Formerly University of Bologna, Bologna, Italy 


\section{The framework}

Emerging and transition economies face different challenges in their technology catching up in light of a modified international framework. Few empirical evidences to underline:

\subsection{A changing world economic framework}

The process of globalization, accompanied by the increasing acceleration of information flows, has enhanced the importance of technological change and productivity growth, which are the fundamental sources of the competitiveness of the economies, for both emerging and advanced countries, although their targets differ in term of innovation' generation and sophistication (incremental or radical innovation): R\&D and Patents in frontier innovations remain highly concentrated in the hand of a limited number of corporations and their affiliates, most of which belong to US and Japan (OECD 2015a). However, this framework is rapidly modifying and the last two decades have foreseen few emerging countries, like China and India, to become increasing competitors, mainly on the low and mediumlow technology segments but also, in some cases, in few high technology sectors. The primary factors that have fundamentally changed the world framework have been the FDI flows and the development of the global value-chain. The FDI-that since the mid-1990s has grown at a faster rate than international trade in goods and services (OECD 2015a), have played the central role in these processes and have been one of the most important vehicle for the recipient countries-developing and transition countries-benefitting of relative low labour costs-not only for employment creation but also technology transfer and knowledge spillovers for the domestic firms. The global value-chain, as result of the fragmentation of production, has reached new stage and has modified the relative position of countries and firms' specializations (UNCTAD 2013). The export of R\&D intensive intermediate manufactured goods since 2000, comes increasingly from non-OECD countries, (OECD 2015a), confirming the rapid insertion of local firms from emerging economies into the global markets, although their benefits depend also at which stage of the value-added chain, they are involved (UNIDO 2015).

\subsection{The development of linkages for favouring spillover effects}

The beneficial effects on the host countries-emerging or transition countriesfrom inward Investments (Markusen and Venables 1999; Javorcik 2002) and participation into the global value chains-beside the other ways through which tacit knowledge' (as embedded into imported capital goods, learning acquisition by migrants etc.) can be channeled-are very diverse. The effects depend upon the improvement of local/national conditions, and the capacity to generate backward linkages between the foreign affiliates and the local firms, as well as from the effectiveness of the domestic policies put in place (UNCTAD 2001; Dulhman 2007; UNDESA 2007). The up-grading of labour' skill, including the capability to learn, 
absorb knowledge and to replicate, is never a linear process and remain often problematic: the combination of manifold different factors including, institutional, organizational, cultural and legal (Nelson and Winter 1982), influence at various degrees, the relative success or failure of such processes.

\subsection{A new paradigm: the "open innovation" approach}

Technological changes and innovations are increasingly result of interaction and connections among different actors and networks (Chesbrough 2006), not only exclusively the results of codified activities (e.g. R\&D) within a defined legal framework-formalized by the Intellectual Property Rights (IPR) system. In a globalized economy, facilitated also by the development of Information and Communication Technology (ICT) that has curbed the costs for accessing to information, the borders between innovation activities-applied research, process and product innovation etc.- - depending on the specificities of the product/sector, on the technology sophistication, on the social relevance (e.g. health and science) and on the related IPR system-might be open to external exchange and collective knowledge. The "open innovation" approach, born subsequent to empirical observation at corporate firm level in a micro-economic perspective (Chesbrough 2003), has moved forward (Gassmann et al. 2010), broadening its fields and focus, encompassing also institutions, in a macro-economic perspective. To this regard, the notion of "open innovation"-in its broad multi-actors version-as the contribution on China in this Special Issue develops, seems an interesting approach that can release new avenues in innovation modalities and experience, in particular for emerging countries.

\section{The core questions in an economic strategy perspective}

The contributions of this Special Issue arise several key questions regarding innovation and technology changes. Among the others, few main fundamental pillars, which have both theoretical and economic strategy relevance, with particular attention to emerging economies, can be highlighted:

\subsection{Exogenous acquisition of technology toward endogenous innovation capability}

The emerging countries face major obstacles in their technology catching up: weak institutional capability both public (government) and private (market institutions), and scarce resources, in term of both quantity (including financial capacity) and quality (technical skill, knowledge, educated labour). In the vision of Rostow' sequential "stages of economic growth" (Rostow 1960), the "take-off" of developing countries, in order to create own science and technology base at a later stage, would be very costly before being able to achieve a critical mass of necessary resources and capability on one side, and very time consuming within a relative long historical track, on the other side. Latecomers cannot follow the 
historical path (Shin 1996; Gerschenkron 1962) of the industrialized countries that have reached their advanced stage and have become high technology economies along centuries of progressive accumulation of capital and then industrialisation. Thus, FDI and technology transfer (Dunning and Naruda 2003), are the main pillars from which a latecomer country can access to a relative sophisticated technology from abroad-jumping, in relative terms, the intermediary steps — and start to build a progressive capacity to learn, absorb knowledge and forge appropriate skill for creating in turn, progressively, own system of innovation (Shin 1996; Kim 1997). The role of the State and institutions in elaborating a long- term strategyfacilitating the access, the transfer and the diffusion of technology (Chang 2003), after having built the basic facilities-is crucial for a successful path toward industrialization and improvement of productivity. The East Asia countries (Mathews 2006), are examples of successful transition toward an innovation society target. Each country has its own technological trajectory that depends on the combination of factor endowment, absorptive capability and technology change (UNIDO 2015) Thus, the external origin of the imported technology does not imply that the domestic utilization is neutral, nor is automatic: the history suggests (Freeman 1995) that a foreign technology can be adapted and transformed by the new needs, bringing implicitly a process of "learning by doing" that might help to master and improve the same technology for better or other scopes. Imitation and reverse engineering-although there is the controversial consequence of the breaking of IPRs, one of the tools for stimulating innovation-are all outcomes that have also, historically, contributed to the improvement and diffusion of technology throughout the economy in the host countries. There is therefore a strong interdependence between the import of technology and the domestic technical development (Freeman 1995) for an emerging economy. China is the recent example of successful combination of both, exogenous and endogenous strategies, along an evolutionary path. The contributions in this Special Issue that present these critical strategic components are those on emerging countries, in particular those on China and India, and on transition economies.

\subsection{Institutional frame and conducive environment for innovation}

The notion of National Innovation Systems, in the various interpretations (Freeman 1987; Nelson 1993; Lundvall 1992; Freeman 1995), following the evolutionary theory perspective (Nelson and Winter 1982; North 1990), emphasizes the importance of the relationships among the different public and private actors in the economy, in order to build a favorable environment for innovation at firm level. Innovation and technology changes are result, therefore, of interactive processes that involve different institutions, including economic, technical, scientific, academic, educational, public administrations, either national or regional (Balzat and Hanusch 2004). Different modes of innovation coexist in the same economy, depending on sectoral or spatial (territorial) patterns, taking into consideration the variety of factors at play, including the cultural and historical ones (Helliwell and Putman 1995), that shape the national or regional contexts (Lundvall 2007). At regional level, the term "Regional Innovationj System" (Asheim and Coenen 2005, 2006; OhUllachain and Kevin 2015) reflects the dominance 
of the regional/local constituents that characterize the technological and structural aspects of the economy involving the regional institutions (Cooke et al. 1997). With the globalization of the economy, the term "national" seems in contradiction (Freeman 1995) with the relative weakening of the "national" policy framework, due to the effects of globalization and/or regionalization (e.g. EU): on the contrary, the effectiveness and efficiency by which national governments pursue (or not) and achieve (or not) public policies - such as education policy, innovation policy, industrial policy etc.-contribute to create favourable (or unfavourable) conditions for the competitiveness of the economy (Nelson 1995). The international competition exercises a pressure on the domestic players - the firms and the other agents - and in order to face rivalry in the domestic as well as in the global markets, they (e.g. the national/local agents) are compelled (or not) to accelerate adaptation and changes: in the negative case, there will be State failure, if public institutions fail in their policy' targets, and/or market failure, if private agents fail to become competitive. Michael Porter (1990) also recognises the "national" level as privileged for shaping the determinants of the competitiveness of an economy. The central role is therefore given to the State as facilitator (North 1990) in managing mechanisms and active policies to improve the quality of the supply, such as labour, sustain the processes that govern innovation and technology transfers and smooth the progress for developing linkages. A stable and predictable institutional frame that pursues coherent policies for sustaining a conducive framework for innovation (Nelson 2005), contribute to create a "system", the other element that composes the National Innovation System' notion. Although the strategies for building a NIS refer primarily to matured market economies, for the institutional capability that is implicitly required, the building of a NIS can become a target of emerging economies' long-term strategy, in their catching up process: the weakness of market institutions lets a large room for an active role of the State, in order to overcome the limited capacities of the private sector, facing also limited resources - that explain then the necessity to attract exogenous resources (FDI/technology transfer) for an exogenous- endogenous complementary strategy. Several papers refer directly or indirectly to the approach in term of NIS or, more in general, they stress the central role of institutions in becoming a leverage in managing technology and innovation processes: the contributions of Vivarelli on the Middle-Income-Trap, Fu, Woo and Hou for China' catching-up strategy, Veugelers and Schweiger on Transition countries, Kaiser for Germany, Romagnoli for Italy, Gokhberg and Roud for Russia.

\subsection{Knowledge as intangible asset: the key role of "human capital"}

The improvement of productivity is predominantly associated with innovation, at the centre of which there are not only hard investments in new technologies and/or related R\&D, but as well intangible investments in "human capital" (OECD 2015a). The term "human capital" condenses manifold aspects such as skill, abilities, knowledge, expertise, and it is crucial in catching-up strategies for ensuring the necessary capacity of learning and the ability to fully exploiting foreign technologies as embodied knowledge (Messinis and Ahmed 2010; MacKinnon et al. 2002): the processes of accumulation of knowledge is essential for the consolidation of the needed absorption capacity (Keller 1996; Figueiredo 2008). Consequently, 
the level of education, skill, and training of labour-or more in general what is called in the broader version "Knowledge-Based Capital" (OECD 2015a; Corrado et al. 2009) that englobes also information, management, and other qualified toolscan be decisive for the creation of favorable conditions for diffusion of innovation, developing linkages and for improving productivity (Nelson and Phelps 1966). Governments have a fundamental role in ensuring tools and framework for enhancing education, training, and opportunities to generate new ideas or facilitating technology dissemination. Therefore the quality of labour, in its various aptitudes and competences, is one of the most strategic component all along the different economic growth trajectories that an economy has taken, depending on its starting conditions: either for ensuring absorption capacity to assimilate and transform imported technology, or for being able to create an endogenous capacity for building own knowledge base, or for trying to be at the technology frontier in the global markets (Corrado et al. 2014). Human capital and the question of the absorption capacity are aspects that have been considered crucial in most of the contributions, in particular in those on Emerging and Transition countries, in this Special issue.

\subsection{Diffusion of innovation and clustering}

The territorial contiguity and the location factors of firms-in the Marshall' conception of clusters - are the concrete background where firms and institutional actors-not only public administrations but as well academic and scientific centres-can built mutual relationships favourable for business development. (Porter 1990) The proximity facilitates the creation of vertical or horizontal interfirm networks in production or services (Torre and Gilly 1999) on the base of differentiation/specialisation' profiles (Robertson et al. 2008), that generate efficiency and economies of scale in the supply-chain, including facilities. Externalities of proximity (Galliano et al. 2015) can also attract new firms, in particular SMEs (Kuah 2002) to join the cluster, facilitated by the low entrybarriers. All these features concur to favor a better matching between demand and supply (the user-producer relations, by Lundvall 1985), facilitating product and process' improvement, contributing to boost an environment favorable to innovation (Feldman 1994). These processes play important role for the diffusion of knowledge and best practices, where "imitation" coexists with "competition" among the same agents within the cluster. Each case is by its own, depending on the economic, technological, institutional, social and cultural background of the territory, region or nation (Boschma 2005; Morgan 2004; Antonelli 2000; Massard and Autant-Bernard 2015). Michael Porter, analysing the clusters cases, comparing Germany and Italy clusters, stresses the relevance of historical and cultural diverse backgrounds where firms, market functioning and organizations are fundamentally diverse, associated to specific firm' behaviors, labour relations, institutional setting (Porter 1990). Silicon Valley in the US (Sturgeon 2003), the Industrial Districts in Italy (Pyke et al. 1990), Bangalore in India (Balatchandirane 2007) etc.: each has own peculiarities and "path dependent", embedded at various degrees, in past economic history (Italy case) or successful replication/imitation of good practices (India case). The cluster 
seems to be a very versatile spatial organisation for technology and innovation up grading, for the importance of the localised character and concentration of quality resources (Feldman 1994), but as well for the policy perspective of successful practices' replication, provided that national or local institutions will sustain these processes adequately. Several contributions to this Special Issue are focused on cluster as component of a strategy of replication, such as India, Taiwan and China, or as part of an historical economic development and/or as economic policy target such as Italy, the US, and Germany.

\section{The contributions}

\subsection{Emerging countries}

The largest number of contributions are dedicated to emerging countries, including India and China, that present strategies and approaches to innovation and technology in their catching-up process. Different ways to channel technology and knowledge transfer are analysed, including FDI, that indicate how difficult is to ensure spillovers for the domestic firms. The contributions highlight the risks, drawbacks and successes of latecomer's cases underlying domestic policies for favoring absorption capacity. The creation of own domestic innovation and technology bases remain the long term target but the institutional capacities and the effectiveness of public policies, including education policies, remain the main critical aspects that require further strengths. The risk of incurring into the Middle-Income Trap (MIT) and the emergence of dualistic economy - an advanced sector/cluster versus a larger poor and traditional economyare the mayor critical risks that an emerging country might encounter in its path to enhancing growth and productivity.

Christine Greenhalgh' contribution ${ }^{1}$ is focused on the relationship between technology transfer, Intellectual Property Rights (IPR) and diffusion of innovation in emerging countries, taking India as case study. She highlights the India' mixed results in term of economic performance for few high technology sectors, associated with highly educated labour forces - against a dominant background of low productivity sectors with poorly educated population, most living in poverty. This kind of "dualism" is the risk faced by many developing countries in their attempt to catching up, the author addressing the problem of poverty and questioning about the possibility to generate an inclusive innovation. The paper further inquiries into the different forms that an emerging country can adopt for acquiring technology, and assessing them under the different angles, when it is evident that there is not a unique answer. The contribution from FDI represents the first most relevant vehicle for favouring diverse forms of technology transfer, training and skill acquisition by local labour; however, spillovers depend on the combination of the different factors and conditions, including policy steps taken by the local policy makers. She underlines the ambivalent outcomes from the TRIPS agreement and the utilization of Intellectual Property Rigths (IPRs) law, that on one side might contribute to create a more conducive framework for further attraction of

\footnotetext{
1 "Science, Technology and IP in India-New Directions and prospects."
} 
FDI, but on the other side, the costs of royalties and licences fees might not facilitate the technology acquisition by domestic firms. The still low level of domestic patenting comparing with China shows the still evident weakness of India 'own capacities to generate innovation. Bangalore one of the India' successful cluster, is the symbol of an effective strategy for high qualified labour, built on the successful combination of abroad academic and skill creation, and then transferred back to the country, contributing to the foundation of domestic highly innovative clusters. The conclusions for the policy perspectives for India underline the critical aspects of the difficult spillover from public science to private industry, the still weak R\&D domestic activities, the still low diffusion of "frugal" innovation among SMEs falling the target toward a more equity and inclusive innovation.

Xiaolan Fu, Wing Thye Woo and Jun Hou, ${ }^{2}$ explores the China'economic strategy for catching up from latecomers to innovation technology, on the way to becoming an innovation-driven economy. The authors adopt an "open innovation" approach from the perspective of the multiplayer actors-institutions, private firms, and MNEs - analysing the different phases by which China went through in its path toward a progressive acquisition of innovation capacity for creating own technology bases. The fundamental phases that have characterised the evolution of technology catching up, started with the reliance on external sources. The authors identify the different ways for technology and knowledge transfer, that reflect the multi-track policy strategy of China:-import of machinery as imbedded technology;acquisition of technology by licenses;-FDI;- - outward investments (e.g. including acquisition of Western companies of particularly high tech-profile);- - students learning abroad and people migration;-international research cooperation;participation into the global-chain value;-other unintended knowledge transfer. The importance of the variety of these different channels has favoured a wide, diversified and progressive acquisition of knowledge, that has generated in turn, the conditions for creation of own endogenous capacities. The absorption capacity is the first step for building new domestic bases for technology and innovation: China' State policy has put forward, during the different phases, vigorous and ambitious programmes for supporting $\mathrm{R} \& \mathrm{D}$, research centres and large firms, for increasing the opportunities and capacities to absorb first, and then, to replicate and multiply the opportunities to build the foundations of own domestic technology base. The State in China has played a pivotal role in adopting a long-term strategy creating a favourable environment, including hard infrastructures and connectivity. Now China needs to consolidate these acquis, the authors underline, for avoiding to be squeezed into the "Middle Income Trap": further reforms in innovation regimes for speeding up skill and technology productions at the frontier, need to be taken and sweeping away from the hard infrastructures investments traditional approach.

Marco Vivarelli, ${ }^{3}$ presents his contribution on the interpretation of "the Middle Income Trap" (MIT) that characterized a large number of emerging countries in their catching up process toward higher income level. Going through an up-date of the literature in the field of innovation and development, starting from a

\footnotetext{
2 "Technological Innovation in China: the lessons and the necessary changes."

3 "The Middle Income Trap: a way Out based on Technological and Structural Change."
} 
Schumpeterian and evolutionary approach, he emphasizes the role of capability and knowledge for building the favorable conditions for economic growth. The empirical evidence of many low income countries, that were able to shift to an upper stage of development having reach the middle income layer -following the transition from low productivity to high productivity sectors - are trapped into a long term stagnating period. The main reasons for such slow-down are to be ascribed mainly to productivity fall, and less to capital accumulation. The competences and capabilities are pre-requisites for improving the capacity to absorb and transform knowledge and technology. The limited financial resources of middle-income countries are an obstacle to investment into domestic R\&D and innovation; the contribution for new technologies come from abroad, where the absorption capacity is necessary, in order to fully exploit the benefit of innovation. The author analyses the different interpretations behind "technology push" and "demand-pull" notions and underlines the necessity for a middle-income country to avoid to be passive, within a de-favorable division of labour, which might narrow its economy to sectoral specializations. Instead, he suggests to adopt active policies for sustaining innovation and improving public support for science and education-creating the necessary infrastructures for enabling technology to be applied. The policy considerations of the author emphasize the central role of education and labour skill, in order to create competences and capabilities, the relevance of active policies-including industrial and innovation policies-for favouring the creation of domestic enterprises. Further, he underlines the risks connected to technology development, as it can bear to increased unemployment-labour saving-and as well to the intensification of inequalities, while productivity growth takes place. The role of the State remains fundamental for creating the best conditions for institutional setting and create new capabilities.

Fukunari Kimura, Tomohiro Machikita and Yasushi Ueki ${ }^{4}$ focus their analysis on the modes of technology transfer by multinationals to emerging countries-taking as case study four countries from ASEAN (Association of South-East Asian Nations). The fragmentation of production with the expansion of the global valuechain - that has represented the primary source for industrialization of these SouthEastern Asian countries-has not been always able to generate domestic capacities for building own industrial base. The effects on labour' skill-that is crucial for increasing domestic innovation capability-has resulted problematic. Among the different possible forms of technology transfer from multinationals-as unintentional spillover from imported machineries, learning by export etc. the authors choose the training as potential path to transmit technical skill and knowledge. The data collection by surveys has been based on buyer-supplier network and as well on inter-firm provision of training for product/process innovation, in order to identify the territorial aspects of acquisition of knowledge and its diffusion. The elaborations confirm the relevance of the Buyer-provided training as a channel of technology transfer with the scope of up-grading vertical links in production network of local firms. The main finding indicate that different favorable factors might facilitate the

\footnotetext{
4 "Technology Transfer in ASEAN Countries: Some Evidence from Buyer-Provided Training Network Data."
} 
provision or the diffusion of training, as geographical proximity to the main buyer in the same country/areas (ASEAN), or if the buyer runs R\&D locally: this latter aspect corroborates the conviction that if $R \& D$ takes place locally, this increases significantly the opportunity for learning by local labour and firms. There is also a kind of chain effect on the training provision, in the case when local and as well, non-local firms have received previously training from main buyer. All these aspects seem to designate that favorable environment and broader strategy by multinationals- in the case it is associated with locally based R\&D-might be positive for the local firms, increasing the opportunities to learn. The authors underline that given the complexity of the topic, the assessment of the impact of FDI by multinationals on the recipient country, remains a large field still to be further enquired, considering the numerous cross factors at play.

K.C. Fung, Nathalie Aminian and Chris Y.Tung, ${ }^{5}$ examine the cases of innovation clusters creation in China and Taiwan taking as a "model" Silicon Valley cluster in California. The different cases analysed in both countries-going through the different phases and policy steps taken-confirm the importance of the clustering activities, as concentration of highly skill/scientific labour forces, common access to facilities and infrastructures, organizational and management efficiency, multiplier effects in attracting new firms at the frontier of technology and in close connections with university and research centres. Silicon Valley has become a benchmark for successful strategy in innovation and new technology, characterized also by its internal dynamics, both as propelling actor and follower, of successive innovation waves, from hardware to software. This dynamic experience, taken place in an advanced country such as California in the US, has become a reference model that has been replicated in different forms and areas, with very distinct background conditions in emerging countries, such as China and Taiwan. The internet economy, and its related "layers model" on the policy side, is emphasized, by the authors, as a potential driven force contributing to faster productivity growth and possibly to facilitate China in its path toward a higherincome economy target. In the case of Taiwan, the high-technology science park as well as the other technology research institutes that have been successful in the previous phases of economic growth, at present seem to be resilient to switch from hardware to software and internet economy, instead of favourable policy incentives taken by the government.

\subsection{Transition countries}

The two contributions on transition economies encompass a large spectrum of countries at very diverse stages of development that have followed different paths, from plan to market: from former USSR to Eastern European countries, to the Balkans. The inherited technology and scientific systems of old planned economies, at the core of which there was Russia, have become obsolete. The process of destruction of the previous economic structures-following the Schumpeter' vision of economic change-has not been followed by the creation of more competitive

\footnotetext{
5 "Some Characteristics of Innovation Activities: Silicon Valley, California, China and Taiwan."
} 
capacities, or only marginally, in few number of countries, among those that integrated the EU. The transition countries-facing shortcoming in their absorption capacity-share a common institutional weakness related to innovation policy that seems to follow too close a Western paradigm, in term of ambitious targets, as the paper of Veugelers and Schweiger suggest, instead of great potential-which has been mainly lost during the two decades of "transition"-of past well-educated and skilled labour.

Reinhilde Veugelers and Helena Schweiger ${ }^{6}$ analyse the innovation policies in the transition countries. The paper highlight how the transition countries-that differ greatly among themselves for their stage of development and market economic consolidation, encompassing former USSR and Balkans countries, but also those Eastern European countries that have joined the European Union-have paid little attention to the necessity to improve the quality of their resources, including labour, and capacity to absorb new technologies. On the contrary, most of the countries have put forward ambitious targets at the frontier of advanced technology, along the same path of developed countries. The dominant role of public funded research organizations leaves on a side the necessity to improve the absorption capacities of private firms, the core actors of innovation. The past legacy of supply-driven approach of innovation and technology policies, that was dominant in all previous planned economies in Eastern Europe-seems to prevail. The authors, by the help of data collection from WEF, have developed an empirical assessment of innovation policies, taking into consideration five major different aggregated factors: Market, Technology access, Absorptive capacity, Creative capacity and Quality of Institutions. The results indicate how still the creative capacities result limited in most of the transition countries. Too little attention have been paid to the quality of institutions and their fundamental role in improving governance, creating a more conducive environment for private firms, contributing to improve the quality of labour and financial markets, for building better conditions for the innovating firms. From a policy perspective, the authors highlight the necessity to give a strategic relevance to the improvement of the institutions and to the absorption capacity at the centre of which there is labour education and skill. In other words, the innovation policies need to be tailored to the specificities of the economic and social conditions of the country.

Leonid Gokhbergand and Vitaly Roud paper ${ }^{7}$ presents an empirical assessment of the determinants of innovation at firm level in Russia. In an unfavorable macroeconomic framework, that has experienced the disruption of previous technological and scientific bases during transition, and the absence of positive changes in the innovation incentive policy-that implicitly suggest a feeble national innovation system-the attempt of the authors is to propose a taxonomy of the innovating firm behavior, identifying the different factors that could explain the persistence of innovation. On the base of data available at firm-level, in a time lag period of 10 years, the elaboration identifies seven innovation taxonomies, that indicate how

\footnotetext{
6 "Innovation policies in transition countries: one size fits all?."

7 "Structural changes in national innovation system: longitudinal study on innovation modes in the Russian industry."
} 
innovating firms are able to improve their position, thanks to a growing sophistication of networking, instead of the heterogeneous conditions, the non favourable market environment and the institutional weakness.

\subsection{Advanced countries}

Two contributions on advanced countries, Germany and Italy, show the different patterns and modalities by which innovation and technology is generated and diffuse in matured market economies. These two Western European countries offer an interesting example of the different role of institutions, that are imbedded into diverse regulatory systems at national level: one formalized and predictable, that of Germany, the other soft and loose, that of Italy, associated with different State role that has its roots also in the different industrialization' history. The competitiveness in selected sectors/branches in the two respective countries, is therefore result of very diverse relations between firms and market, associated with supportive organisations for innovation and technology and sustained by robust national policies, in the German case (for exemplification, one among the highest R\&D spending in Europe), or by weak and fragmented policy framework in Italy (one among the lowest R\&D spending in Europe). We can deduce that Italy has an extremely fragile NIS that let individual firms/cluster to perform without evident supportive national framework, although, it can enjoy of conducive environment in few clusters/areas located in the regions in the North/North-East, on the base of which Putman (1993) has elaborated the notion of "social capital", one of the features of the Italian "Industrial Districts"'s past innovation performance.

Robert Kaiser paper" ${ }^{8}$ analyses the German experience in innovation and technology policies, taking as concrete cases two representative sectors-biotechnology and mechanical engineering. His analysis starts from the perspective of the National Innovation System (NIS) approach, developed mainly by Lundvall and Nelson, underlying the role that institutions can have in creating interrelations and favourable conditions for supporting innovation and research for new technologies. The advantages of German economy in technological performances can be ascribed to the positive interactions between private sector and public institutions. The author disagrees with the analysis in term of "varieties of capitalism" by Hall and Sockice (Hall and Sockice 2001), because they considers Germany as an example of "coordinated market economy", with a more incremental type of innovation, against "liberal market", such as the US and the UK, with more radical type innovation: this "typology" would not explain the performance in selected high technologies sectors in Germany. He underlines the relevance of the territorial dimension, shifting the notion of NIS to the regional level, as "Regional Innovation System". Along this line, the innovation system has been re-organised and reconfigured at regional level and this is consistent with the federal character of the German State: the region (Land) has acquired increasing powers in defining the innovation policy. The analysis of the two sectors, biotechnology and mechanical

\footnotetext{
8 The institutional foundation of innovativeness and competitiveness of two German industries: biotechnology and mechanical engineering compared.
} 
engineering, provides good examples of successful policy strategies: the first focused on the creation of new capacities adopting "a cluster oriented approach" learning from past failures; the second, starting from consolidated historical industrial background, mainly path-dependent, but facilitating a continuous upgrading of the technology system, combining national/federal support programmes to regional/Land policies incentives. The conclusion of the author underlines the appropriateness of the notion of "National Innovation System" as a tool for analysing the innovation capacity and competitiveness of countries.

Alessandro Romagnoli and Manuel Romagnoli ${ }^{9}$ present the case of the Italian innovation system as a peculiar type among the industrialised countries. Italy scientific and innovation base, as R\&D spending on GDP, is recorded within the lowest rate among Western European countries, indicating a relative weak technology-driven economy, where public institutions do not play actively for sustaining innovation. Although this critical picture the authors, following a Langlois' interpretation (Langlois 2003), analyse the peculiarity of the Italian industrial model: the dominant weight of Small and Medium size Enterprises (SMEs), comparing with the other competitors in the European context, reflects different modalities by which innovation takes place, is applied and diffused. The paradigms on which lay the competitiveness of many SMEs, corroborated by their export performance, is substantially based on not-codified innovation activities that take place not in the universities or R\&C centres, but within the firms or within the Industrial District framework: "Innovation without R\&D", as the authors mention. The IPR and Patents system, very costly for small companies, have been often ignored and this can explain partially, the very low levels of recorded Patents in Italy. The factors that play typically for the competitiveness of the industrial firms in Italy, mainly organized in cluster as "industrial district", the authors mention, are the following: -high plant or firm specialization, contributing to economy of scale;-qualified labour and vocational on the job training;-high division of labour and integration among local firms;--high product specialization and differentiation, in each cluster;-competition among the firms of the cluster, not based on price, but mainly on quality and differentiation of the product, or on new products and on customer service. These characteristics show how innovation and high quality products can respond better and quicker to both domestic and foreign market demand. This SMEs model of industrialization therefore is not only related to firm size but as well to different modalities through which innovation and competitiveness are reached. The small size of the firm and the high degree of specialization facilitate the introduction of flexible technologies and create the better conditions for becoming competitive. The increasing pressure from globalization on domestic market, and the recent financial crisis have eroded past advantages and this model suffers from the lack of stable and sound overall institutional "national" support policies. The weakness of the national framework for technology and innovation is one of the core hindrance of the Italian competitiveness.

\footnotetext{
9 "The innovation in the evolution of the "Italian industrial model": lights and shadows."
} 


\section{Conclusions}

Few main policy considerations can be drawn, taking into account the varieties of the conditions and the complexity of the phenomena that are involved. There is no blueprint for innovation policy (OECD 2015b) and good mix of policies need to be tailored to the different economic backgrounds, where emerging, transition and advanced countries, have each own peculiar priorities, although similarities subsist among tools and processes.

1. A Long-term commitment by governments for boosting innovation is fundamental for emerging countries, but as well as for mature economies. Stable, predictable and sound public policies are necessary either for mastering a wayout from backwardness, or for improving competitiveness for technology frontier' strategy. Among emerging countries, the example of China confirms the importance of choosing a long-term evolutionary approach, going through different stages, that foresees an implicit learning by doing step by step, conjugating external and domestic resources endowment' strategy. Among advanced countries, competitiveness performance' disparities, show how market mechanisms, in term of innovation capacity, work differently: the "varieties of capitalism" (Elsner and Hanappi 2008) analysis suggests complex combinations of structural and institutional factors, that influence competitiveness and growth, far beyond the stylized neo-classic wisdoms. So each country has also own specific technology and innovation trajectory.

2. The relevance of the business environment for enhancing innovation. Depending on the relative backwardness or maturity of the economy and on the existing socio-economic conditions, innovation policy needs to be tailored to the specificities of the context/country, addressing the structural and economic rigidities, barriers and disparities. The role of government (national/regional) is crucial for contributing to the creation of overall conditions favourable to innovation, facilitating relationships between local players (firms and institutions) as well as international cooperation (trade and cooperation policies). The creation of conducive framework is therefore a priority for enhancing any ambitious policy targeted to innovation and technology: in emerging countries, this necessarily deals also with hard barriers constraints.

3. Policies' complementarity for sustaining innovation. The innovation policy cannot be exclusively related to $R \& D$ and innovation activities, but needs to be matched by other complementary policies, combining tangible and intangible investments, which are directly or indirectly related to innovation. Education policy, in particular for emerging countries, is the key policy, accompanied by appropriate labour policy for improving local labour market. Industrial policy can have a particular relevance for emerging countries, for facilitating a process of industrialization, matching FDI and/or global value-added chain, focusing in particular on small-medium firms. Other policy targets, that address the structural weakness or barriers to business, are also essential such as those focused on building facilities, connectivity (ICT) services as well as mobility 
(infrastructures). Appropriate fiscal and financial policies accompanied by specific incentives for innovation, are widespread practices among emerging, but as well as advanced countries: their effectiveness depend upon the overall regulatory framework and institutional capability. This large set of complementary policies-that need to be modulated case by case-in a macro-micro combination perspective, is a fundamental pre-requisite for tackling inconsistencies and obstacles to innovation, in both emerging as well as advanced countries.

4. The spatial concentration of innovating firms: the relevance of the proximity. The innovation oriented clusters, and their widespread replication in many emerging countries, like China and India, confirm the importance of the creation of territorially concentrated firms' critical mass, vertically or horizontally integrated, accompanied by high skill local labour, having multiplier effects into the economy, and often improving export competitiveness. The globalization of the markets does not reduce the importance of the territory (Barca et al. 2002; Morgan 2004): on the contrary, the conducive local conditions can enhance the capacity of firms to be competitive for the concentration of knowledge, savoir-faire, entrepreneurial capacity.

5. The risks connected to innovation and technology changes: increase of unemployment and inequalities. Whilst new technologies and innovation can contribute primarily to productivity growth, the effects on employment might not be positive, depending on the specific technological and economic circumstances. Labour saving is a dominant trend that is occurring in advanced countries, given their cutting-edge technologies applied throughout all the sectors of the economy. Emerging countries might not suffer at the same pace, as they still have large and long-lasting needs for economic and technological restructuring, but it is a risk that will also emerge in perspective. The other consequences that might occur is the increasing of the inequalities, as restructuring and reallocation of resources bring most of the time also concentration of revenues and marginalization of the weak social brackets. The inequality phenomena is increasing worldwide, and technological change might accelerate such trend, even if not being the only source of such outcome.

6. The ambivalent aspects of innovation diffusion' modalities: imitation and reverse engineering are informal ways through which technology and innovation can be diffused among other firms/sectors of the economy, or be exploited for learning purpose from imported foreign technology' embedded knowledge (Chang 2001). However, these processes, on the other side, might go against the respect of the Intellectual Property Rights (IPR)/Patents system (e.g. counterfeit), that are essential to regulation and competition among firms in the local or global markets. These contradictory aspects do not involve only emerging countries versus advanced countries, but are widespread phenomena that interest the same market functioning in advanced countries, as imitation is also linked to diffusion (example of cluster' innovation diffusion), depending also on the specificities of the cases, and on the socio economic contexts. These conflictual phenomena coexist and have not a unique solution, but depend on the interests and forces that are behind, for the regulation of the competition in the local/global markets. 
Behind the identification of the right policy targets and of a balanced policy-mix for innovation, effectiveness and efficiency by which these same policies are implemented, are crucial. This in turn depends on the institutional capacity and capability that have been consolidated so far in each country/region.

\section{References}

Antonelli C (2000) Collective knowledge, communication and Innovation: the evidence of technological districts. Reg Stud 34(6):535-547

Asheim BT, Coenen L (2005) Knowledge bases and Regional Innovation Systems: comparing Nordic clusters. Res Policy 34(8):1173-1190

Asheim BT, Coenen L (2006) Conceptualising regional innovation systems in a globalising learning economy: on knowledge bases and institutional frameworks. J Technol Transf 31(1):163-173

Balatchandirane G (2007) IT clusters in India. Institute of developing economies, discussion paper n.85, January

Balzat M, Hanusch H (2004) Recent trends in the research on National Innovation Systems. J Evol Econ 14(2):197-210

Barca F, McCann P, Rodriguez-Pose A (2002) The case for regional development intervention: place versus place-neutral approaches. J Reg Sci 52(1):134-152

Boschma RA (2005) Proximity and innovation: a critical assessment. Reg Stud 39(1):61-74

Chang H-J (2001) Intellectual property rights and economic development: historical lessons and emerging issues. J Hum Dev 2(2):287-309

Chang H-J (2003) Globalization, economic development and the role of the state. Zed Book, TWN, Penang

Chesbrough H (2003) Open innovation: the new imperative for creating and profiting from technology. Harvard Business Press, Cambridge

Chesbrough H (2006) Open Innovation: a new paradigm for understanding industrial innovation. In: Chesbrough H, Vanhaverbeke W, West J (eds) Open innovation: the new paradigm. Oxford Univesity Press, Oxford, pp 1-27

Cooke Ph, Uranga MG, Etxebarria G (1997) Regional Innovation systems: institutional and organizational dimensions. Res Policy 26(4-5):475-491

Corrado C, Hulten C, Sichel D (2009) Intangible capital and US economic growth. Rev Income Wealth 55(3):661-685

Corrado C, Haskel J, Jona-Lasinio C (2014) Knowledge spillovers, ICT and productivity growth. In: The conference board and Georgetown University Imperial College, CEPR and IZA, discussion paper No. 8274, IZA

Dulhman C (2007) Technology, globalization, and intellectual competitiveness: challenges for developing countries. Industrial Development for the 21th Century: Sustainable Development, UNDESA, New York, pp 29-83

Dunning J, Naruda R (eds) (2003) Foreign direct investments and governments: catalysts for economic restructuring. Routledge, London

Elsner W, Hanappi G (eds) (2008) Varieties of capitalism and new institutional deals: regulation, welfare, and new economy. Edward Elgar Publishing, Cheltenham

Feldman MP (1994) The geography of innovation. Kluwer Academic Publisher, Dordrecht

Figueiredo PN (2008) Dynamics of endogenous capability building and the role of technological learning processes in developing countries: some issues for the agenda of corporate management and government policy. UNESCO High level Working Group on Technology and Development, Manchester

Freeman C (1987) Technology, policy and economic performance: lessons from Japan. Pinter Publisher, London, New York

Freeman C (1995) The "National System of Innovation" in historical perspective. Camb J Econ 19(1):5-24 
Galliano D, Magrini M-B, Triboulet P (2015) Marshall's versus Jacobs' externalities in firm innovation performance: the case of French industry. Reg Stud 49(11):1840-1858

Gassmann O, Enkel E, Chesbrough H (2010) The future of open innovation special issue the future of innovation. R\&D Manag 40(3):213-221

Gerschenkron A (1962) Economic backwardness in historical perspective. Harvard University Press, Cambridge

Hall PA, Soskice D (eds) (2001) Varieties of capitalism: the institutional foundations of comparative advantage. Oxford University Press, Oxford

Helliwell JF, Putman RD (1995) Economic growth and social capital in Italy. East Econ J 21(3):295-307

Javorcik BS (2002) Does foreign direct investment increase the productivity of domestic firms? In search of spillovers through backward linkages. World Bank Policy Research Working Paper n. 2923

Keller W (1996) Absorptive capacity: on the creation and acquisition of technology in development. J Dev Econ 49(1):199-227

Kim L (1997) Imitation to Innovation: the dynamics of Korea's technological learning. Harvard Business School Press, Boston

Kuah ATH (2002) Cluster theory and practice: advantages for the small business locating in a vibrant cluster. J Res Mark Enterp 4(3):206-228

Langlois RN (2003) The vanishing hand: the changing dynamics of industrial capitalism. Ind Corp Change 12(2):351-385

Lundvall BA (1985) Production Innovation and user-producer interaction. Aalborg Universitetsforlog, Aalborg

Lundvall BA (ed) (1992) National systems of innovation: toward a theory of innovation.Authem Press, London

Lundvall BA (2007) National innovation systems-analytical concept and development tool. Ind Innov 14(1):95-119

MacKinnon D, Cumbers A, Chapman K (2002) Learning, innovation and regional development: acritical appraisal of recent debate. Prog Hum Geogr 26(3):293-311

Markusen JR, Venables AJ (1999) Foreign direct investment as a catalyst for industrial development. Eur Econ Rev 46(2):335-356

Massard N, Autant-Bernard C (2015) Geography of innovation: new trends and implications for public policy renewal. Reg Stud 49(11):1767-1771

Mathews JA (2006) Catch-up strategies and the latecomer effect in industrial development. New Polit Econ 11(3):313-335

Messinis G, Ahmed AD (2010) Cognitive skill, innovation and technology diffusion. CSES working papers No 48

Morgan K (2004) The exaggerated death of geography: learning, proximity and territorial innovation systems. J Econ Geor 4:3-21

Nelson RR (ed) (1993) National innovation system, a comparative analysis. Oxford University Press, Oxford

Nelson RR (1995) Co-evolution of industry structure, technology and supporting institutions, and the making of comparative advantage. Int J Econ Bus 2(2):171-184

Nelson RR (2005) Technology, institutions and economic growth. Harvard University Press, Cambridge MA, London

Nelson RR, Phelps S (1966) Investments in humans, technological diffusion, and economic growth. Am Econ Rev 56(1/2):69-75

Nelson RR, Winter SG (1982) An evolutionary theory of economic growth. Harvard University Press, New York

North DC (1990) Institutions, institutional change and economic performance. Cambridge University Press, Cambridge

Ó hUallacháin B, Kevin K (2015) Regional aspects of collaborative invention across national innovation systems. Eur Plan Stud 3(11):2227-2252

OECD (2015a) Science technology and industry outlook 2016, Paris

OECD (2015b), The Innovation Imperative: contributing to productivity, growth, and well-being, Paris Porter ME (1990) The competitive advantage of nations. The Free Press Edition, New York

Putnam RD (1993) The prosperous community. Am Prospect 4(13)

Pyke F, Beccattini G, Sengenberger W (1990) Industrial districts and inter-firm cooperation in Italy. International Institute for Labour Studies (IILS), Geneva 
Robertson PL, Jacobson D, Langlois RN (2008) Innovation processes and industrial districts. University of Connecticut, working paper 2008-03, January

Rostow WW (1960) The stages of economic growth. Cambridge University Press, Cambridge

Shin J-S (1996) The economics of the Latecomers: catching up, technology transfer and Institutions in Germany, Japan and South Korea. Routledge, London

Sturgeon TJ (2003) What really goes on in silicon valley? Spatial clustering and dispersal in modular production. MIT working paper, IPC-03-001

Torre A, Gilly JR (1999) On the analytical dimension of proximity. Reg Stud 34(2):169-180

UNCTAD (2001) World investment report 2001-promoting linkages. United Nations, New York

UNCTAD (2013) World investment report 2013: global value-chains: investment and trade for development, United Nations, New York, Geneva

UNDESA (2007) Industrial development for the 21th century: sustainable development, New York

UNIDO (2015) Industrial development report 2016-the role of technology and innovation in inclusive and sustainable industrial development, Vienna 